\title{
Patterns in spatial distribution of venture capital and Private Equity investments in Brazil
}

Gilberto Gilberto Sarfati

Pós Doutor em estratégia empresarial pela FGV

Professor da Fundação Getúlio Vargas - FGV

Marcus Salusse

Doutor em Administração e Professor da Fundação Getulio Vargas - FGV/SP

Editor Científico: José Edson Lara

Organização Comitê Científico

Double Blind Review pelo SEER/OJS

Recebido em 20.01.2018

Aprovado em 25.08.2018 


\begin{abstract}
The study examines patterns in spatial distribution between venture capital and private equity investors and investees in Brazil. A survey was conducted using the geographic location data of venture capital and private equity fund managers and investee companies who were part of the Second PE/VC Census (ABDI \& FGV, 2011). The database contained 144 PE/VC fund managers and 481 investee companies by the year 2010. Distances between managers and investees of $63 \%$ of the database or $50 \%$ of the total number of firms in the Brazilian PE/VC industry were randomly obtained and analysed. Results indicate regional equity gaps and inequality of the spatial distribution of the Venture Capital industry in Brazil.
\end{abstract}

Keywords: regional equity gap; venture capital and private equity

\title{
Padrões de Distribuição Espacial de Investimentos em Capital de Risco e Private Equity no Brasil
}

\section{Resumo}

O estudo examina padrões de distribuição espacial entre investidores de capital de risco e de private equity e investidas no Brasil. Foi realizada uma pesquisa utilizando os dados de localização geográfica de gestores de fundos de capital de risco e de participações privadas e empresas investidas que faziam parte do Segundo Censo de PE / VC (ABDI \& FGV, 2011). O banco de dados continha 144 gerentes de fundos de PE / VC e 481 empresas investidas até o ano de 2010. As distâncias entre gerentes e investidas de $63 \%$ do banco de dados ou $50 \%$ do número total de empresas na indústria brasileira de $\mathrm{PE} \mathrm{/} \mathrm{VC} \mathrm{foram} \mathrm{obtidas} \mathrm{aleatoriamente} \mathrm{e}$ analisadas. Os resultados indicam lacunas regionais de equidade e desigualdade na distribuição espacial da indústria de Venture Capital no Brasil.

Palavras-chave: lacuna de equidade regional; capital de risco e private equity

\section{Patrones en la distribución espacial del capital de riesgo y las inversiones de capital privado en Brasil}

\section{Resumen}

El estudio examina los patrones en la distribución espacial entre el capital de riesgo y los inversionistas e inversionistas de capital privado en Brasil. Se realizó una encuesta utilizando los datos de ubicación geográfica de los administradores de fondos de capital de riesgo y de capital privado y empresas participadas que formaron parte del Segundo Censo PE / VC (ABDI y FGV, 2011). La base de datos contenía 144 gestores de fondos de PE / VC y 481 compañías participadas para el año 2010. Se obtuvieron y analizaron al azar distancias entre los administradores y las participadas del $63 \%$ de la base de datos o el $50 \%$ del número total de empresas en la industria brasileña de PE / VC. Los resultados indican brechas en la equidad regional y desigualdad en la distribución espacial de la industria del capital de riesgo en Brasil.

Palabras clave: brecha de equidad regional; capital de riesgo y capital privado 


\section{Introduction}

The development of VC industry for fostering high impact entrepreneurship and its importance for regional development is widely acknowledged (Alchleitner et al., 2009; Florida \& Kenney, 1988; Martin, Bernard, Klagge, \& Sunley, 2005). Accordingly, since 2001 and primarily through the INOVAR program of the Financier of Studies and Projects (Financiadora de Estudos e Projetos - FINEP), the Brazilian government has been seeking to contribute to the reduction of existing equity gaps by fostering the development of the VC industry. The investment funds originated from PE/VC corresponded to $2 \%$ of the country's gross domestic product (GDP) (ABDI \& FGV, 2011). This recent development of the industry through FINEP activity has contributed to the early development of the risk capital industry and focused on the growth of the number of high-impact entrepreneurs in Brazil.

The VC literature emphasizes that particularly during the initial and developmental phases of companies there is a need for spatial proximity between the fund manager and the investee company (Bender \& Lutz, 2009; Harding, 2000/ Lutz et al., 2013). The assumption underlying this hypothesis is that agency and transaction costs are expected to be lower in deals where investors and investee are closer. Besides, it is recognized that non-financial support is crucial to success in the initial stages of development of the company and local networks can facilitate first contact and relationship building between entrepreneurs and risk capitalists, which is recognized to influence the costs of pre-investment screening, due diligence, and postinvestment monitoring. Therefore, high-impact entrepreneurs based in cities distant from the cities of the fund managers would have a lower probability of receiving investments on comparable projects that could leverage their enterprise. That is, for these entrepreneurs, there would be a distance cost or a liability of distance (Harding, 2000; Martin, Bernard, Klagge, \& Sunley, 2005).

Most studies on geographic distribution of Venture Capital (VC) are focused on mature markets, mainly in European countries, Canada and the United States. However, the literature remains limited with respect to the role of development of $\mathrm{VC}$ in the developing economies, characterized by the existence of institutional voids and the active role of the government, such as Brazil. Recently, Zang (2011), investigating the Chinese VC industry, concluded that in the case of China the geographic concentration of investments is higher than in mature markets because of regulatory and normative deficiencies of the country. Nevertheless, data from the Second Census of Private Equity and Venture Capital (ABDI \& FGV, 2011) indicate that 79.7\% of Brazilian VC fund managers do not agree that a target company being located more than 
$100 \mathrm{~km}$ from the fund manager is a reason to decline an investment, and only $13.6 \%$ recognized this distance as a limiting factor.

Within this context, the study analyses patterns in spatial distribution between venture capital and private equity investors and investees in Brazil. It investigates whether the recent development of the VC industry has generated a regional equity gap in investments in VC funds focused on the early stages of enterprise development. The spatial distribution of VC and PE investments and the role of the state in the development of regional networks of investors and entrepreneurs are explored as well.

The method employed was a survey of VC and PE fund managers who were part of the Second Census of Private Equity and Venture Capital (ABDI \& FGV, 2011) based on the geographic location data provided in the census and the geographic location of the investee companies. The database contained $144 \mathrm{PE} / \mathrm{VC}$ fund managers and 481 investee companies in the portfolio by the year 2010 , which represent $80 \%$ of the total number of companies in the sector. From the total database, 305 distances were obtained randomly, which corresponds to $63 \%$ of the database or $50 \%$ of the total number of firms in Brazil's PE/VC industry. Although the database may seems outdated this census remains the last largest and detailed conducted in the Brazilian market.

First, a statistical description of the data regarding the different characteristics of the companies that constitute the database was performed. Next, linear and ordered logistic regressions of the data were conducted with the objective of obtaining the spatial distribution patterns of fund managers and their investees. This research contributes to the literature on entrepreneurship and $\mathrm{VC}$ by describing the unequal regional distribution of the $\mathrm{VC}$ investments in Brazil.

\section{Literature review}

Several studies note the importance of developing a VC industry as an essential factor for promoting entrepreneurship (Barry, 1990; Gompers \& Lerner, 2009; Hellmann \& Puri, 2000). The recent literature on VC and high-impact entrepreneurship emphasizes the role of government in fostering a VC industry and high-impact entrepreneurship as most important (Cumming, 2007; Lerner \& Watson, 2008). More specifically, the activity of the government in the regional development of the relationship between VC and high-impact entrepreneurship has been recognized as crucial (Avnimelech, Schwartz, \& Bar-El, 2008; Florida \& Kenney, 
1988; Harding, 2000). In contrast, Michael and Pearce (2009) suggest that the government should promote (high-impact) entrepreneurship because it encourages innovation and, therefore, relates positively to wealth creation.

In developing economies and emerging markets, the formal institutional structures are often absent or deficient. In these circumstances, an institutional void arises, which increases transaction costs and limits economic growth (Khanna \& Palepu, 1997). There is a consensus in the literature that the government shapes the institutional structures by encouraging certain activities and discouraging others (Minniti, 2008). Therefore, governments tend to structure policies that can encourage the development of entrepreneurship to promote the development of an entrepreneurial culture (Audretsch, Keilbach, \& Lehmann, 2006; Keilbach, Tamvada \& Audretsch, 2009).

Sunley, Klagge, Berndt, and Martin (2005) observed that in countries such as the United Kingdom, France and Germany the programs to foster the VC industry have a regional dimension. The regionalization is justified because knowledge and local networks can be used to overcome information asymmetries and regional initiatives to foster $\mathrm{VC}$ can be best leveraged in coordination with other initiatives to promote innovation and incubators. The issue of spatial distance between potential VC investors and potential high-impact entrepreneurs refers to a weak network relationship among them and, therefore, the role of the state in fostering regional development.

For Harding (2000), investments of this type of VC should not be regarded as a universal solution for the growth of the country's GDP but as contribute to the rapid growth of highimpact entrepreneurs. The VC literature demonstrates that in the United States and other developed economies clusters of VC funds and high-impact entrepreneurs are common (Chen, Liu, \& Chen, 2009; Leinbach \& Amrhein, 1987; Subhash, 2007). Fritsch and Schilder (2006) indicate that the proximity of the $\mathrm{VC}$ and the investee company in Germany is often a precondition for investment because geographic proximity facilitates the supervision by the investors. Sorenson and Stuart (2001) examined the distance between VC funds and investee companies in the dispersed and mature US market and demonstrated that the probability that a VC investor will choose another target for the realization of its capital investment declines sharply as the distance between the VC investor and the investee company increases. For Zook (2004), the ability of an investor to support a new enterprise depends on a series of contacts and networks of personal relationships that depend on the spatial proximity between the investor and the entrepreneur. Analysing the internet industry, Zook (2002) reinforces the argument that 
the regional distribution of venture capital is of central role in determining the location of new internet startups.

Green (2004) summarizes two major explanatory models for the regional concentration of VC investments: the geographic model and the diffusion model. The first model postulates that certain regions have certain characteristics, such as an industrial/corporate culture and knowledge networks that promote the concentration of investments. The second model advocates that VC funds are initially concentrated in major financial centers. Then, the funds gradually move to new centers of high-technology development. As these centers are consolidated, new local funds that specialize in local knowledge begin to arise, that is, specialized local area networks of VC, and high-impact entrepreneurs would be created.

Martin et al. (2005) reports clear evidences of spatial constitution of the venture industry in both Germany and United Kingdom. The study identifies national differences between the two countries but identifies the concentration of venture capital firms in clusters on more developed regions and the existence of equity gaps on apparently deprecated regions (Martin $e t$ $a l ., 2005)$. Recently, Lutz et al. (2013) concluded that the probability of a financing relationship in Germany, which has a dense transport infrastructure, decreases by $8 \%$ if the journey time increases by on standard deviation, which reinforces the impact of spatial proximity in the likelihood of an investment. High impact entrepreneurs from deprecated regions are expected to bare liabilities of distance regarding the disadvantage in getting comparable projects funded due to the additional costs involved in screening, due diligence and monitoring (Florida and Kenney, 1988; Lutz et al., 2012; Zook, 2002).

Agency theory is often used to explain the increase of costs related to informational asymmetries and conflicts of interest between a venture capitalist as principal investing in a company managed by an entrepreneur as agent (Lerner, 1995; Sapienza \& De Clercq, 2000; Sapienza \& Gupta, 1994). Although there are bonding and monitoring mechanisms to mitigate agency problems (Gompers, 1995; Kaplan \& Strömberg, 2001), uncertainty is a natural component of VC industry deals and venture capitalists evaluates it based on criteria such as the characteristics of the entrepreneur, the product or service, the market and the financial situation of the firm (Kollman \& Kuckertz, 2010; Lutz et al, 2012). The higher the uncertainty, the higher the expected return to compensate for the additional costs associated with the deal (Chen et al, 2010). In this sense, screening, due diligence and monitoring companies located closer to investors are less expensive and time-consuming transit-wise. Proximity is also an 
efficiency factor for venture capitalists on providing non-financial support, arranging personal meetings, assessing personal networks and obtaining reliable information about the entrepreneurial team and the development of the investee company. Transaction costs theory has also been used to understand investment decisions of venture capitalists as the sum of transaction costs can be used to evaluate alternative deals (Williamson, 1981). The relationship between venture capitalists and portfolio companies relates to information costs, negotiation costs and monitoring costs and these costs increase with distance and journey time due to less familiarity with the market the investee is located, to travel expenses and time of transit (Lutz et al., 2012).

In addition, social exchange theory also supports distance as dependent variable as social relationships are developed on the basis of trust, reciprocity and reputation in an interactive increase of commitment from both parties (Larson \& Starr, 1993; Lutz et al., 2013). As such, the establishment of social relationships between investors and investees may influence cooperative behaviour and reduce information asymmetries (De Clerq \& Sapienza, 2001; Shane \& Cable, 2002). It is expected that social interactions necessary to develop stable relationships are more likely to occur if investors and investees are closer form each other, facilitating first contact and reducing the costs needed to build the relationship. As argued, the three theories support the argument for the distance as a dependent variable on assessing venture capitalists decision to invest.

Zang (2011), investigating the Chinese VC industry, concluded that in the case of China the geographic concentration of investments is higher than in mature markets because of institutional voids, which amplifies the role of the state in stimulating the development of regional networks of investors and entrepreneurs in order to foster the VC industry and economic growth. Evaluating the case of high-tech companies in China, Liu (2011) notes that the institutional void harms the activity of these companies and that it can be compensated in the case of companies that operate within technological parks, in particular those owned by the State. The absence of incentive policies that regionally foster VC can impair growth in the stock of high-potential companies in regions without VC firms due to the importance of spatial proximity. Therefore, the understanding of the development of the VC industry is an important factor to foster regional development and economic growth which is even more pronounced in emerging economies such as Brazil.

In Brazil, the first state mobilizations intended for developing the risk capital activity occurred through the National Bank for Economic and Social Development (BNDES) and by FINEP in 
1974 and in 1976, respectively. Private initiatives began in the 1970s. However, because of the absence of institutionalization (i.e., the private equity firms) and their origin in the form of holdings, such initiatives were not registered by Brazil's Securities and Exchange Commission (Comissão de Valores Mobiliários-CVM). Therefore, according to Pavani (2003), from the legal perspective, these companies conducted only the usual commercial transactions of purchase and sale of shares.

Brasilpar is considered by the market to be Brazil's first risk capital company. Its operations began in 1976 when the company was founded because of the partnership of Unibanco with the company Paribas. The partnership aimed to stimulate the investment of risk capital in the country. After five years, the company modified its operational and share structures as well as its objectives, to become a risk capital firm. Notably, the greater part of the company's operations was focused on the information technology sector, in which Brasilpar acquired the control of many companies. In the 1990s, the company focused its activities on corporate finance advisory services. Until today, the company focuses exclusively on this type of service.

During the 1980s, the Brazilian economy was characterized by high instability and volatility, primarily because of high inflation. This conjuncture discouraged risk capital activity in the country. However, according to Pavani (2003), during this period, certain initiatives were of the utmost importance for the development of this industry in Brazil: BNDESPar, Brasilpar and the CRP Shareholdings Company (Companhia de Participações-CRP).

BNDESPar is an organization that arose from the unification of Embramec, Fibase and Ibrasa, which occurred in 1982. Even today, the institution is a reference point in the Brazilian risk capital industry because it has acted for many years as a fund investor and on other occasions as a direct investor. As a fund investor, BNDESPar aimed at the development of regional companies whose capital was risk capital. As a direct investor, this organization acted in two ways: direct investments and by means of the Program for the Capitalization of Technology-Based Firms (Programa de Capitalização de Empresas de Base TecnológicaContec), which was created in 1991 to support the development of risk capital by providing assistance to innovative companies. The company received support from agencies that aim at fostering this sector, such as the Brazilian Development Bank (BNDES) (Mendonça, 2008). CRP is another precursor of the risk capital market in Brazil. It was founded in 1981 because of many investments by large private and state groups from Rio Grande do Sul State and by the 
Development Bank of Rio Grande do Sul (Badesul). CRP remains active and is considered the oldest Brazilian risk capital company. The most substantial government action to foster the VC industry in Brazil was that of FINEP in 2001, when the Inter-American Development Bank's (IDB)'s Multilateral Investment Fund (MIF) contributed US\$ 1.12 million of the US\$ 3.7 million construction budget of the first INOVAR fund.

One of INOVAR's first fostering mechanisms was the INOVAR Venture Forum, which provides training to entrepreneurs and connections with potential investors through events at which entrepreneurs present their businesses and interact among themselves and with potential investors. Through INOVAR I, that lasted from 2001 to 2006, several PE and VC companies, such as Stratus, DGF and Fir Capital, managed to raise funds. During this period, Lupatech, an industrial valve manufacturer heavily focused on the petroleum industry, participated in the first Venture Forums and after several rounds of investment was launched on the stock market in 2006. Through the attraction of pension funds, during this period, there was a significant development of the industry, particularly in the PE area.

During INOVAR (2007-2012), the goal became the development of the subsequent links in the chain focused on VC and financing mechanisms for early stage enterprises (seed money). More recently, INOVAR started to support the formation of angel investor networks. From 2001 to 2011, INOVAR attracted 17 partners, including 11 pension funds, and contributed to approximately 24 funds to raise more than US\$ 2 billion. In 2003, after publication of Instruction no. 391, which regulated $\mathrm{PE}$ funds, $\mathrm{PE} / \mathrm{VC}$ investments significantly increased in Brazil. That is, the capital committed by the PE/VC industry increased from US\$ 5.6 billion in 2004 to US\$ 36.1 billion in 2009 according the second Brazilian census of the PE/VC industry (ABDI \& FGV, 2011).

Overall, it can be argued that has been substantial effort from the Brazilian government to promote the development of the VC industry in the country, but the effects of that effort are still unknown. In a developing country of substantial territorial extension, such as Brazil, it is likely that the VC industry is unequally distributed regionally due to the importance of spatial proximity and the existence of regional institutional voids. Even in regions in which there is a latent potential for high-impact entrepreneurs, the growth cycle of companies is incomplete because of the absence of VC companies that are interested in investing away from their head office. 


\section{Methods}

This study evaluates the effect of distance between the VC and PE fund manager and investee companies based on data from the Second Census of Private Equity and Venture Capital (ABDI \& FGV, 2011). The research hypotheses are the following:

Hypothesis 1a. The likelihood for spatial distance between companies is lower for VC fund managers and their investees.

Hypothesis 1 b. The likelihood for spatial distance between companies is higher for PE fund managers and their investees.

Hypothesis 2a. The distance between risk capital fund managers and their investees is greater for corporate ventures.

Hypothesis $2 \boldsymbol{b}$. The distance between risk capital fund managers and their investees is greater for companies from the public sector.

Hypothesis 3. The distance between risk capital fund managers with more experience (age) and their investees is smaller than the distance of the fund managers with less experience and their investees.

Sample Description. The research was conducted with the data on the geographic location of the VC and PE fund managers who were part of the Second Census of Private Equity and Venture Capital (ABDI \& FGV, 2011) and the geographic location of both parties. The database contains $144 \mathrm{PE} / \mathrm{VC}$ fund managers and 481 investee companies in portfolio by the year 2010, which represents $80 \%$ of the number of companies of Brazil's PE and VC industry. The survey follows the nomenclature adopted by the census and with regard to the research object and the simplification of the analyses only the distinction between investments characterized as VC and PE was maintained. This database remains the latest and largest one about the sector

VC fund managers concentrate their investments during the early stages of development of the investee companies. The initial stage consists of seed investments (small investment during the preoperational phase) and start-up investments (capital investments during the structuring phase), which generally occur during the first two years of operation. This stage of development includes VC (early stage investments) companies with already tested products or services and with up to four years since establishment and $\mathrm{R} \$ 8$ million in revenues. Then, the second round of investment occurs for VC (later stage investment) companies with a need for cash flow for accelerated growth and operational improvement, which is usually related to the 
third and fourth rounds of investment. PE fund managers concentrated on enterprises in the expansion or maturity stages. Generally, the target enterprises of PE investments are medium or large size and, in accordance with the nomenclature established for the BNDES, have revenues that exceed $\mathrm{R} \$ 16$ million (ABDI \& FGV, 2011). The PE-growth expansion stage consists of companies already established on the market with consolidated products and brands, which attracts resources for expansion. The maturity stage consists of a PE (later stage companies) platform for the expansion and consolidation of firms in the same sector as well as companies in restructuring (distressed companies) or large real estate and infrastructure projects in addition to forestry investments.

Regarding the management form or the type of PE/VC company five different types of PE/VC fund managers were considered in accordance with the nomenclature used by the Second Census of Private Equity and Venture Capital (ABDI \& FGV, 2011). The risk capital fund firms, whether PE or $\mathrm{VC}$, may be independent (open capital or closed capital) and have independent fund managers who obtain resources from third parties or investments in financial assets and are professionals dedicated to PE/VC investments. The fund managers can also be of the corporate-venture type, which are conglomerates and corporations with specific resources for PE/VC investments in technology and high impact. The fund managers may be linked to certain financial institutions, which normally have sectors focused on PE/VC asset management resources, or to the public sector, for example, BNDES. From a total of $144 \mathrm{PE} / \mathrm{VC}$ fund managers who participated in the census, $81 \%$ were employed by independent enterprises. Of these enterprises, the large majority consisted of independent closed capital companies $(75 \%)$. A small number were independent open capital companies, that is, companies that have shares traded on the stock market (6\%). PE/VC fund managers linked to financial institutions represent $9 \%$ of the total, followed by companies in the public sector $(8 \%)$ and corporate ventures $(2 \%)$.

Dependent Variable: Distance between Fund Managers and Investees. When analyzing the distance between the PE and VC fund management companies and the companies in which they invest, several different variables are used in the literature, such as the spherical distance (Lerner, 1995), car travel time (Fritsch \& Schilder, 2008) and minimum travel time (Lutz et al, 2013). In this study, we use the distance in kilometers between the companies (Sorenson \& Stuart, 2001), while remaining aware of the variable limitations regarding long distances because of the possibility of using air transportation. Despite this restriction, the use of distance in kilometers enables us to assess the validity of the assumptions that this study proposes. That is, the distance in kilometers between the fund managers and investee companies 
enables the identification of existing standards and the importance of the proximity between the companies with respect to funding, particularly during the early stages of development, which is referred as VC investments.

With the intention to obtain data related to the spatial distribution of the companies, the postal codes (CEP) or the addresses of the PE/VC fund managers and the investee companies were initially obtained. The information on the location of the companies was obtained by searching on their websites. When such information was absent, the information used was obtained from the CVCepe - Endeavor guide (2008), which is a study that outlines a general overview of the PE and VC fund managers in the country. The identification of the National Juridical Person Registration (CNPJ) of the companies was another resource used to locate companies when the previous two alternatives were unsuccessful. With a Google search of the company's name and CNPJ, it is possible to obtain the registration data of the company through a cadastral survey on the Federal Reserve website, which contains data on the company and the address of its registered head office. Once the business location was determined, Google Maps was used to obtain the distance in kilometers between the managers and the investee companies. When the $\mathrm{PE} / \mathrm{VC}$ firm had offices or subsidiaries in more than one location, we assumed that the office nearest the investee company was responsible for the business. If the target company had offices or subsidiaries in more than one location, the nearest office from the investors was considered for the analysis. From the total database for 2010, which contains $144 \mathrm{PE} / \mathrm{VC}$ fund managers and 481 companies in portfolio and represents $80 \%$ of the total number of companies in the sector, 305 distances between fund managers and investee companies were obtained randomly, which corresponds to $63 \%$ of the database or $50 \%$ of the total number of companies in Brazil's $\mathrm{PE} / \mathrm{VC}$ industry. The distances between $\mathrm{PE} / \mathrm{VC}$ fund managers were analyzed together and, in some cases, the analyses of PE/VC fund managers and their investees were separated for better understanding of the pattern for the two investment modalities.

Independent Variables. Stage of development of the investee companies. The information on the type of investment received by investee companies was obtained from the database of the Second Census of Private Equity and Venture Capital (ABDI \& FGV, 2011). The division between PE and VC investments enables the differentiation of the stage of development of these companies. PE investments are related to more advanced stages of development of companies, whereas VC investments are related to the initial stages of development. 
Type of risk capitalist. The variable related to the type of risk capitalist was also obtained from the CVCepe - Endeavor guide (2008) and, when data were lacking, from company websites or directly contact. The categories used in this study relate to the CVCepe Endeavor guide (2008) nomenclature, which categorizes the fund managers as independent (open or closed capital) corporate ventures linked to a financial institution and fund managers from the public sector.

Experience of risk capitalists. The age of the risk capital fund managers has been used as a proxy for experience. The data regarding the start of a fund manager's operations in Brazil was obtained from the CVCepe - Endeavor guide (2008) and, when data were lacking, from the company website. Missing data were also obtained using a Google search to obtaining the company's CNPJ, which was used to access the companies' certificate of cadastral circumstances through the Federal Reserve website, where the foundation date could be found.

Control Variables. In addition to the dependent variable and the independent variables used in the study, several variables were obtained to control exogenous effects that may influence the distance between the risk capital fund managers and the investee companies. To control any potential differences in social and economic development between the municipalities in which the investee companies are located, the United Nations Human Development Index (IDHM) from 2010 for the respective cities was included in the model. Based on the dimensions of income, education and health, the IDHM enables the control of structural differences related to the three dimensions and decreases a possible influence of socioeconomic differences of these municipalities on the investment decision and, as a consequence, of the distance between the fund managers and the investees. Additionally, $\mathrm{PE} / \mathrm{VC}$ managers can differently perceive the opportunities afforded by regions with a labor shortage or low income. Thus, information about the per capita income and the population in municipalities in which the investee companies are located was obtained. All of these data were collected from the Brazilian Institute of Geography and Statistics (IBGE) and the United Nations Development Program (UNDP) Web sites.

Procedures. To better identify the differences between the PE and VC investments in Brazil, frequency distribution was performed in three different ways: one with the global data from the database and, subsequently, with the data related to PE and VC investments separately. The frequency distribution was performed using intervals of $100 \mathrm{~km}$, which represents the distance that can be traveled in up to an hour and a half by car, that is, distances liable to be travelled round trip in a single travel day. The following intervals $(100-300 \mathrm{~km})$ represent 
distances that can be traveled by car but that present limitation of the time and distance that can be comfortably traveled in a single day. The interval of $400-500 \mathrm{~km}$ represents the distance between several of the major cities in which the investee companies are located, particularly Rio de Janeiro and São Paulo. In this case, the distance would not be travelled by car but by air, with the possibility of a round trip on the same day. Intervals longer than $500 \mathrm{~km}$ represent longer trips to be traveled by car or air (taking into consideration Brazil's continental proportions). In addition, ordered logistic regression was used to investigate the likelihood of distance between managers and investees. Various robustness checks were conducted to verify the empirical results presented in the study and linear regressions, Tobit models and multinomial logistic regressions were tested, suggesting that the results are robust.

\section{Results}

Figure 1 shows that the spatial distribution of PE investments is concentrated in the range of up to $500 \mathrm{~km}$ from the fund manager (78\%). More specifically, half of investments are up to $100 \mathrm{~km}$ from the fund manager. Figure 2 shows that $69 \%$ of the VC investments are up to $100 \mathrm{~km}$ from the fund managers.

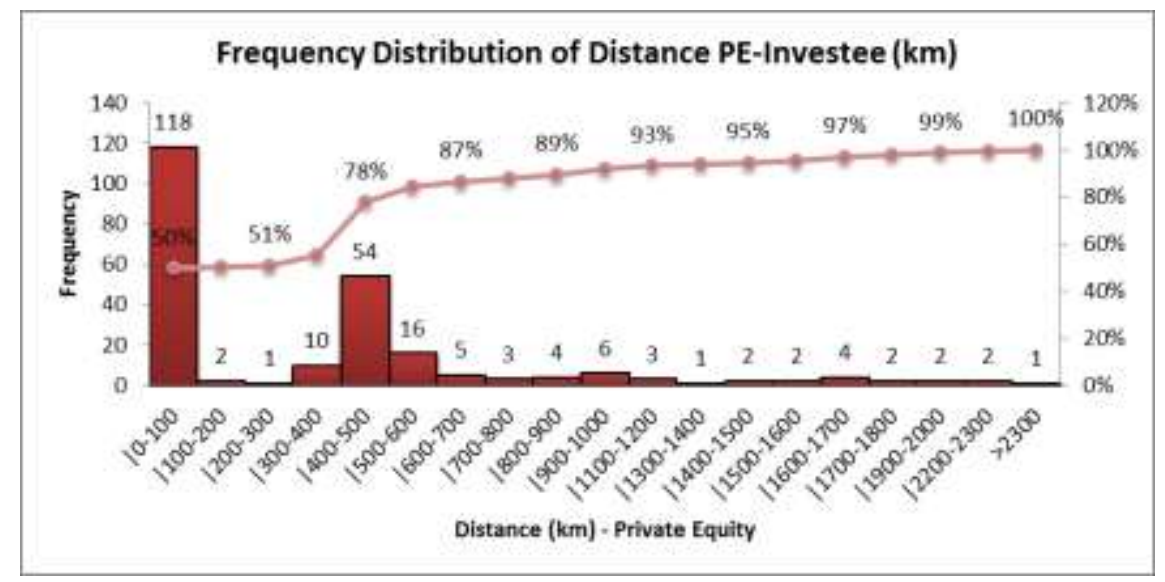

Figure 1. Frequency Distribution: Private Equity 


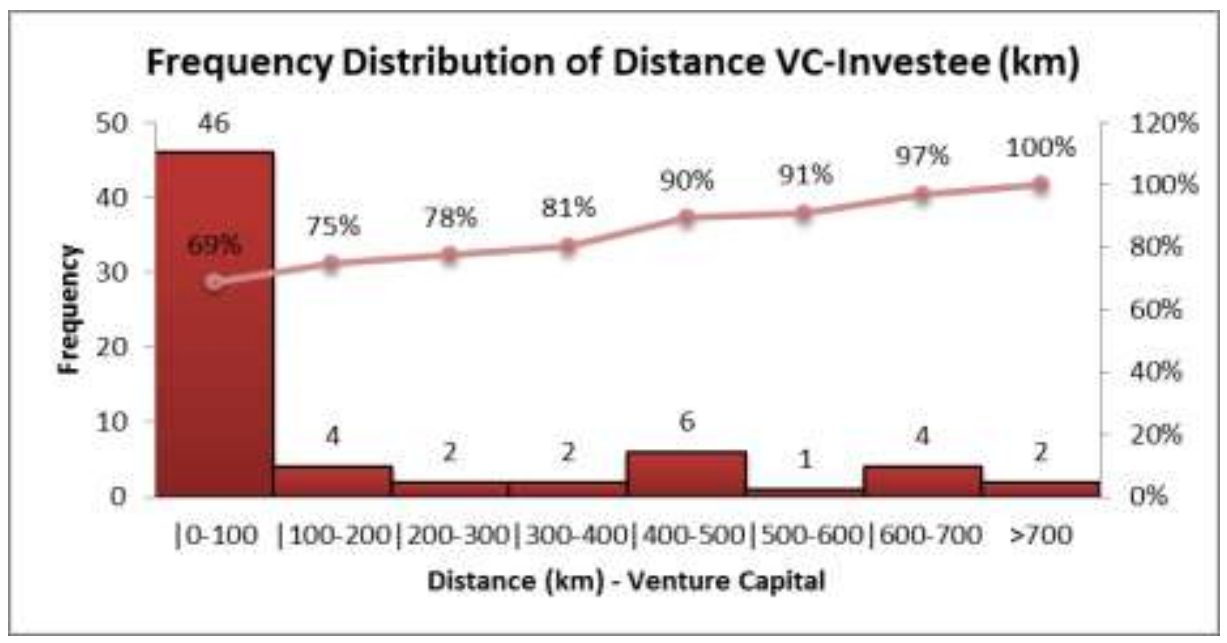

Figure 2. Frequency Distribution: Venture Capital

Figure 3 shows the dispersion of the distances between the risk capital fund managers and the companies that have received investments accounted for in the Second Census of Private Equity and Venture Capital (ABDI \& FGV, 2011). Analyzing the data related to the PE and VC fund managers separately, it is possible to see that the mean $(142 \mathrm{~km})$ and the median $(8.8 \mathrm{~km})$ of the distances between the VC fund managers and investees are considerably smaller than the mean $(358 \mathrm{~km})$ and median $(133 \mathrm{~km})$ distances between PE fund managers and investees. Both sets of dispersion results evidence distances of $1 \mathrm{~km}$, which demonstrates that there are many managers and investees in the PE/VC industry who are located less than one kilometer from each other.

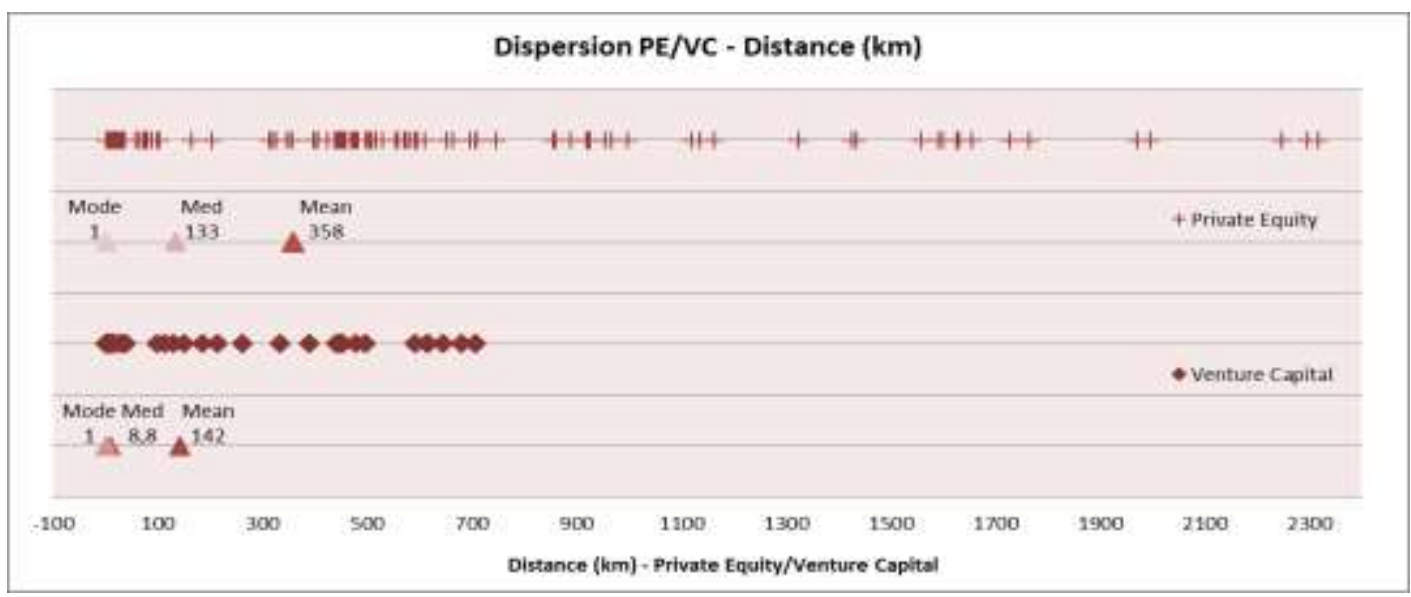

Figure 3. Dispersion/Distance $(\mathrm{km})$ : PE/VC 
The distribution of fund managers per state (Figure 4) enables us to identify the existence of a large regional concentration of $\mathrm{PE} / \mathrm{VC}$ fund managers in Brazil. A total of $95 \%$ are located in the Southeastern Region, with a large concentration in São Paulo (65\%) and Rio de Janeiro (26\%). The only region that also has a significant number of PE/VC fund managers in its territory is the Southern Region (5\%) in the states of Rio Grande do Sul (3\%), Santa Catarina (1\%) and Paraná (1\%). The plotting of the information obtained through research in Brazil facilitates the accurate understanding of the data and provides clear evidence of the concentration of the PE/VC industry in the Southeastern Region, with a small number of companies located in the Southern Region. Analysing PE and VC fund managers separately, it can be observed that the concentration of PE managers is greater than that of the VC fund managers. A total of $98 \%$ of the PE fund managers are located between São Paulo (68\%) and Rio de Janeiro (30\%). In addition, $95 \%$ of the VC fund managers are concentrated in four states: São Paulo (52\%), Minas Gerais (18\%), Rio Grande do Sul (14\%) and Rio de Janeiro (11\%). Regarding the investee companies, a large concentration occurs in the Southeastern Region $(80 \%)$ in addition to a significant number of companies in the Southern Region (11\%), which together correspond to $91 \%$ of the total number of investee companies in Brazil. The breakdown of the companies that have received PE investments presents a concentration of $81 \%$ in the Southeastern Region, $8 \%$ in the Southern Region and $10 \%$ in other regions. Regarding VC investments, $76 \%$ occurs in the Southeastern Region, $21 \%$ in the Southern Region and the remaining 3\% in other regions. A total of $40 \%$ of the investments are concentrated in the city of São Paulo, whereas 15\% are concentrated Belo Horizonte and 7\% in Rio de Janeiro (Figure $5)$. 


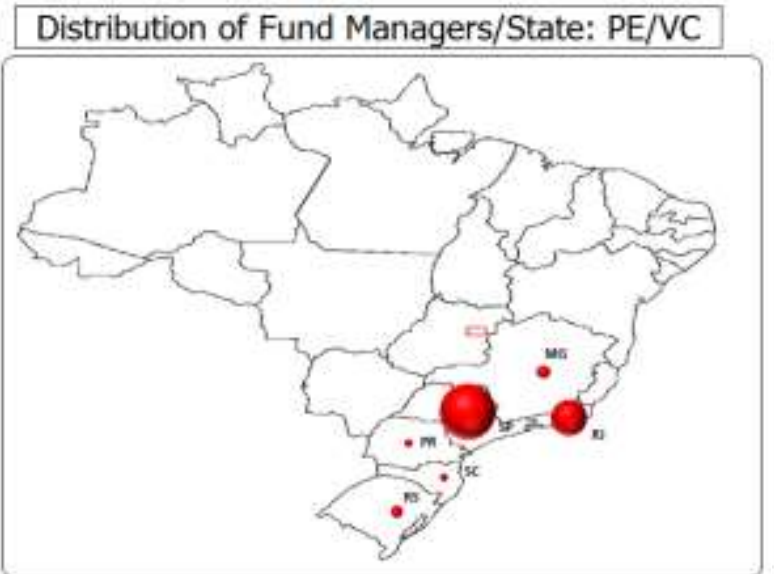

Figure 4. Distribution of Fund Managers/State:

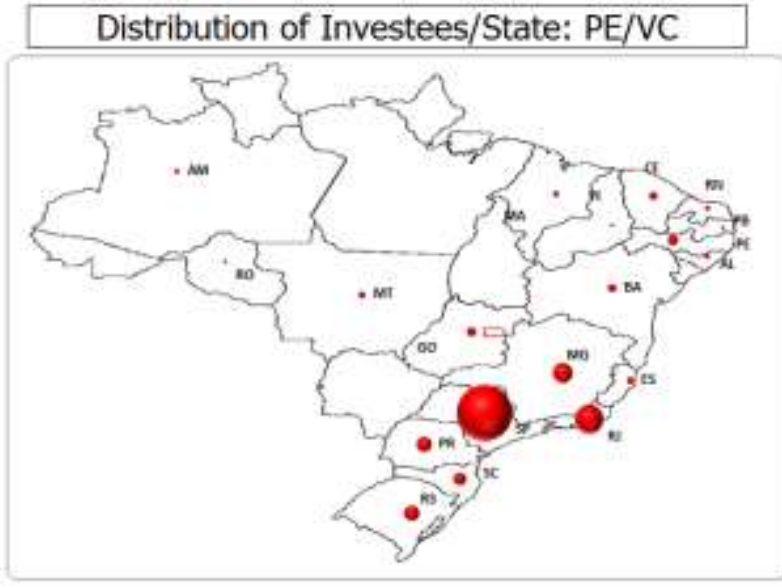

Figure 5. Distribution Map of Investees/State: $\mathrm{PE} / \mathrm{VC}$

Another important element in the survey refers to the experience of risk capital fund managers. In this study, we used age as a proxy for fund manager experience, given the influence that the experience of managers has on the size and geographic dispersion of their contact and investment network (Sorenson \& Stuart, 2001). The experience achieved over the years enables venture capitalists to access a more comprehensive network of contacts and opportunities, which arise from previous investments. The sample data were analyzed separately for PE and VC fund managers, and the dispersion of the age of the fund managers (Figure 6) shows similar values for both groups. This outcome indicates that the majority of Brazil's risk capital fund managers began during the 1980s and 1990s, whereas the younger fund managers began during the mid-2000s.

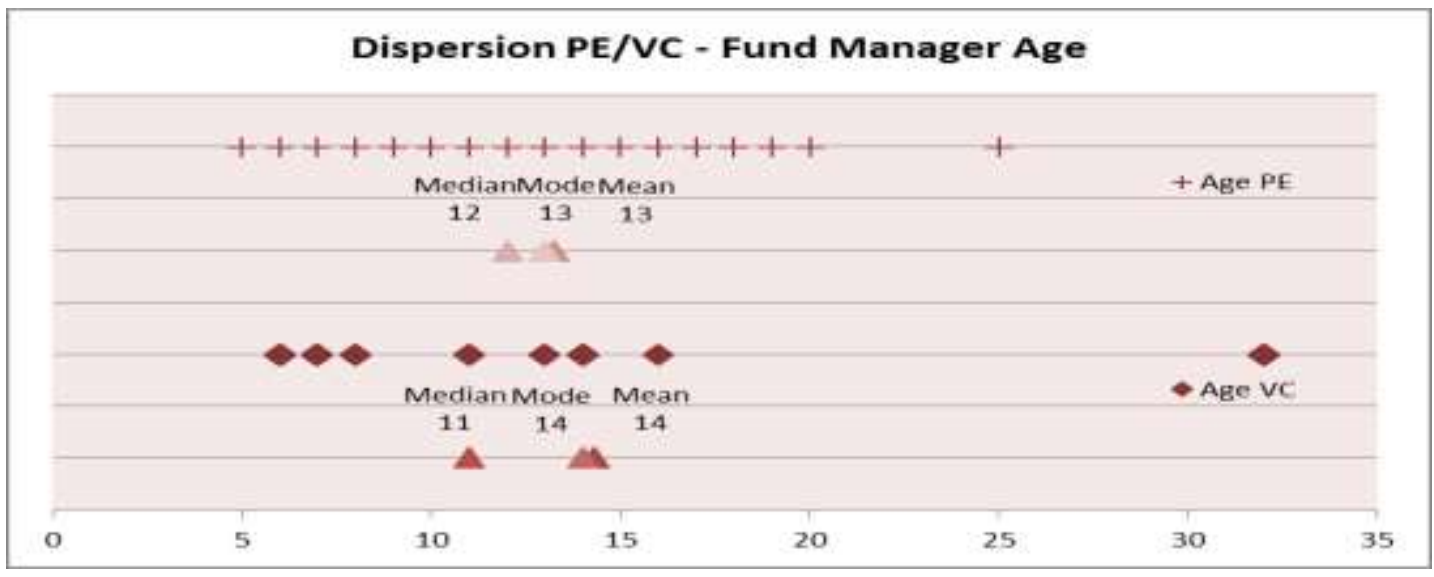

Figure 6. Frequency Distribution of Fund Managers/Age 
According to a correlation matrix (Table 1), the correlation between the dependent variable distance in kilometers and the model's other variables are fairly small and statistically not significant in most cases but reveals first bivariate relationships.

\section{Table}

Correlation Matrix

\begin{tabular}{|c|c|c|c|c|c|c|c|c|c|c|c|}
\hline Correlation Matrix & $\begin{array}{c}\text { Distance } \\
\text { _km }\end{array}$ & $\begin{array}{l}\text { Time } \\
\text { min }\end{array}$ & $\begin{array}{c}\text { Dummy } \\
\text { VC }\end{array}$ & $\begin{array}{l}\text { Dummy } \\
\text { CCapital }\end{array}$ & $\begin{array}{l}\text { Dummy } \\
\text { CVenture }\end{array}$ & $\begin{array}{l}\text { Dummy } \\
\text { Finstitut }\end{array}$ & $\begin{array}{l}\text { Dummy } \\
\text { Psector }\end{array}$ & Age & $\begin{array}{c}\text { IDHM } \\
\text { Venture }\end{array}$ & $\begin{array}{l}\text { Percapta } \\
\text { Income } \\
\text { Venture }\end{array}$ & $\begin{array}{l}\text { Population } \\
\text { Venture }\end{array}$ \\
\hline Distance_km & 1.000 & & & & & & & & & & \\
\hline Time_min & 0.7004 & 1.000 & & & & & & & & & \\
\hline DummyVC & -0.2022 & -0.1910 & 1.000 & & & & & & & & \\
\hline DummyCCapital & -0.2216 & -0.2472 & 0.3325 & 1.000 & & & & & & & \\
\hline DummyCVenture & -0.1048 & 0.0289 & -0.0871 & -0.2619 & 1.000 & & & & & & \\
\hline DummyFInstitution & 0.0708 & 0.1991 & -0.1752 & -0.5271 & -0.0542 & 1.000 & & & & & \\
\hline DummyPSector & 0.2666 & 0.1458 & -0.1910 & -0.5745 & -0.0591 & -0.1189 & 1.000 & & & & \\
\hline Age & 0.1737 & 0.0965 & 0.0624 & -0.3819 & -0.0028 & -0.0525 & 0.5528 & 1.000 & & & \\
\hline IDHMVenture & -0.4679 & -0.6809 & -0.0786 & 0.0926 & 0.0248 & -0.1769 & 0.0192 & -0.0903 & 1.000 & & \\
\hline PercaptalncomeVenture & -0.4297 & -0.6407 & -0.1037 & -0.0832 & 0.0178 & -0.1543 & 0.0314 & -0.0438 & 0.9605 & 1.000 & \\
\hline PopulationVenture & -0.4219 & -0.4972 & -0.101 & 0.0417 & 0.0834 & -0.0826 & -0.0453 & -0.2401 & 0.7341 & 0.6293 & 1.000 \\
\hline
\end{tabular}

IDHM: Index of human development for cities

Table 2 summarizes descriptive statistics and Table 3 shows the ordered logistic regression results. The dependent ordinal variable contains five categories and refers to the distance in kilometers between $\mathrm{PE} / \mathrm{VC}$ risk capital fund managers and the companies that received investments based on the Second Census of Private Equity and Venture Capital (ABDI \& FGV, 2011) 
Table 2

Summary of Descriptive Statistics

\begin{tabular}{|c|c|c|c|c|c|}
\hline Variable & $\mathbf{n}$ & Mean & Standard Dev & Min & Max \\
\hline \multicolumn{6}{|l|}{ Spatial Distribution/Distance } \\
\hline Distance $(\mathrm{km})$ & 305 & 310.699 & 443.105 & 1 & 2317 \\
\hline Time (min) & 305 & 258.820 & 414.665 & 5 & 2460 \\
\hline \multicolumn{6}{|l|}{ Target Companies/Investees } \\
\hline \multicolumn{6}{|l|}{ Stage of development } \\
\hline DummyVC & 481 & 0.2037 & 0.4032 & 0 & 1 \\
\hline \multicolumn{6}{|c|}{ Risk Capital Fund Managers/Investors } \\
\hline \multicolumn{6}{|l|}{ Typology PE/VC } \\
\hline Dummy ClosedCapital & 481 & 0.7484 & 0.4344 & 0 & 1 \\
\hline Dummy CorporateVenture & 481 & 0.0249 & 0.1561 & 0 & 1 \\
\hline Dummy FinantialInstitution & 481 & 0.0852 & 0.2795 & 0 & 1 \\
\hline Dummy PublicSector & 481 & 0.0769 & 0.2667 & 0 & 1 \\
\hline \multicolumn{6}{|l|}{ Experience PE/VC } \\
\hline Age & 434 & 12.635 & 6.307 & 5 & 32 \\
\hline \multicolumn{6}{|l|}{ Control Variables } \\
\hline IDHM Venture & 481 & 0.7639 & 0.3256 & 0.631 & 0.824 \\
\hline Percaptalncome Venture & 481 & 994.624 & 182.829 & 360.34 & 1715.11 \\
\hline Population Venture & 481 & $2.90 \mathrm{e}+07$ & $1.46 \mathrm{e}+07$ & 1562409 & $4.13 e+07$ \\
\hline
\end{tabular}

Model OL1 includes all variables in their original linear form. Model OL2 includes the logarithm of Age and Population of the investee municipality due to its relative variation and to be better fit of the model. In consequence, Model OL2 provides better statistical fit to the data and will the used in the following discussion of results of the study. The better fit of Model OL2 is indicated by a higher Nagelkerke's $\mathrm{R}^{2}$ of $38,5 \%$ and a smaller Akaike Information Criterion (AIC) of 645.628. 
Table 3

Ordered Logistic Regression: Dependent Variable $=$ Ordinal Distance $(\mathrm{km})$

\begin{tabular}{|c|c|c|c|c|c|}
\hline \multirow{2}{*}{ Dependent variable } & \multirow{2}{*}{$\begin{array}{r}\text { OL1 } \\
\mathrm{P}>|z|\end{array}$} & \multicolumn{4}{|c|}{ OL2 } \\
\hline & & Odds Ratio & Coef. & $z$ & $\mathrm{P}>|\mathrm{z}|$ \\
\hline \multicolumn{6}{|l|}{ Ordinal Distance_km } \\
\hline DummyVC & $0.000^{* * *}$ & 0.1946387 & -1.63661 & -4.34 & $0.000^{* * *}$ \\
\hline DummyCCapital & 0.975 & 0.9237937 & -0.0792665 & -0.14 & 0.889 \\
\hline DummyCventure & 0.111 & 0.0574787 & -2.85634 & -1.78 & 0.075 \\
\hline DummyFInstitution & 0.594 & 0.5842726 & -0.5373876 & -0.79 & 0.427 \\
\hline DummyPSector & 0.014 & 4.535714 & 1.511983 & 2.31 & 0.021 \\
\hline Age & 0.219 & -- & -- & -- & -- \\
\hline LogAge & --- & 1.553101 & 0.4402535 & 1.35 & 0.176 \\
\hline IDHMVenture & 0.051 & $5.51 e+13$ & 31.64017 & 1.78 & 0.076 \\
\hline PercaptalncomeVenture & $0.003^{* * *}$ & 0.9917307 & -0.0083037 & -2.84 & $0.004^{* * *}$ \\
\hline PopulationVenture & $0.000^{* * *}$ & -- & -- & -- & -- \\
\hline LogPopVenture & --- & 0.2593751 & -1.34948 & -5.03 & $0.000^{* * *}$ \\
\hline /cut1 & 18.00942 & & -6.233074 & & \\
\hline /cut2 & 18.17348 & & -6.068729 & & \\
\hline /cut3 & 19.7693 & & -4.451142 & & \\
\hline /cut4 & 20.69464 & & -3.479547 & & \\
\hline $\mathrm{N}$ & 305 & & 305 & & \\
\hline LR Chi ${ }^{2}$ & 127.27 & & 132.40 & & \\
\hline Nagelkerke's $\mathrm{R}^{2}$ & 0.373 & & 0.385 & & \\
\hline McFadden's Ajd R ${ }^{2}$ & 0.135 & & 0.141 & & \\
\hline AIC & 650.756 & & 645.628 & & \\
\hline
\end{tabular}

H1: Stage of Development of the Investee Companies. The inclusion of the dummy variable for $\mathrm{VC}$ investments enables us to analyze this type of investment compared with PE investments and the likelihood to pertain to each ordered logistic categories. The results indicate statistical significance with $95 \%$ confidence interval in both models and confirm Hypothesis 1a and $1 \mathrm{~b}$ showing that on average investee companies that received $\mathrm{VC}$ funding exhibit lower spatial distribution (distance) from the fund manager, thus been placed closer to them. It can be said that by receiving a $\mathrm{VC}$ investment instead of a PE investment (going from 0 to 1 ) it is expected a 1.64 decrease in the log odds of being in a higher level of distance from the fund manager. Besides, results indicate that, on average and in relation to the median, the companies that received $\mathrm{VC}$ investment are closer (a shorter distance in kilometers) than the companies that received PE investments, which reinforces the validation of Hypothesis 1a and $1 \mathrm{~b}$ of this study. 
Similarly, the correlation matrix (Table 1) indicates that VC investments are negatively correlated with the Corporate Venture fund managers and positively correlated with the manager age, which means that with respect to the variable Corporate Venture the distance tends to be greater as a function of manager age.

H2: Type of Risk Capitalist. The correlation matrix indicates a negative correlation for between distance and Corporate Venture, which represents a trend that opposes the hypothesis, and a positive correlation with public sector fund managers, which agrees with the hypothesis for the Brazilian context and differs from the hypotheses elaborated for more mature economies. The ordered logistic regression presented in Table 3 reflects the correlation observed in correlation matrix and facilitates the identification of a correlation between the variables and the distance but without statistical significance, which makes it inappropriate to confirm Hypotheses $\mathrm{H} 2 \mathrm{a}$ and $\mathrm{H} 2 \mathrm{~b}$

H3: Venture Capitalists' Experience. The age of the PE/VC fund manager was used as a proxy for experience. The logarithm of age was used in Model OL2 as it makes economic sense and for better fit. The results of the ordered logistic regression indicated a positive correlation between the age of the PE/VC fund managers and the investee companies but without statistical significance. In this respect, it is inappropriate to validate Hypothesis 3 of this study. Table 4 summarizes the results found in this study.

\section{Table 4}

Summary of Hypotheses and Results

\begin{tabular}{lcc}
\hline Hypotheses table & Expected impact & Result \\
\hline Target Companies/Investees & & \\
Stage of developmentent & - & Confirmed \\
H1a: likelihood of distance is lower for venture capital & + & \\
H1b: likelihood of distance is higher for private equity & & \\
\hline Risk Capital Fund Managers/Investors & + & Not significant \\
Typology PE/VC & - & Not significant \\
H2a: corporate venture & & \\
H2b: public sector & - & Not significant \\
Experience PE/VC & &
\end{tabular}




\section{Conclusions}

The objective of this paper was to examine the relationship between distance and the spatial distribution of $\mathrm{PE} / \mathrm{VC}$ investments in Brazil by investigating patterns of spatial distribution of the PE/VC industry in the country. The statistical description of the data was performed for the different characteristics of the companies that constitute the database and it allowed the identification of major regional inequality. Additionally a ordered logistic regression of the data was performed to obtain the spatial distribution patterns of the fund managers and their investees. A five-category ordinal variable for distance in kilometres was used as a dependent variable. The following were used as independent variables: (i) the stage of development of the investee companies; (ii) the type of risk capital fund manager; and (iii) the age of the risk capital fund managers as a proxy for their experience. Finally, control variables related to the United Nations Human Development Index (IDHM) of the municipality in which the investee companies are located were included in the model in addition to the per capita income and the population of these municipalities.

The study's results indicate that the investee companies that received investments from VC fund managers (early stages of development) are geographically closer to the investee companies than the investee companies that received PE investments. The results corroborate Hypothesis 1 of the study and reinforce the argument in relation to the importance of the proximity between startup companies and risk capital fund managers.

The geographic concentration of $\mathrm{VC}$ fund managers and investee companies in the Southeastern Region and to a lesser extent in Southern Brazil is remarkable. This concentration has important implications and draws attention to the need for public policies for investors in regions in which there is an equity gap. Such policies represent a means to stimulate innovation and economic and social development in the Northern, Northeastern and Central-Western Regions.

Therefore, given the current regional equity gap, high-impact startup companies from the Northern, Northeastern and Central-Western Regions of Brazil have little chance of receiving investments and the support that $\mathrm{VC}$ fund managers typically provide. Thus, their chance of growth is much lower compared with startup companies, particularly those startup companies located in the cities of São Paulo, Belo Horizonte and Rio de Janeiro. 
Similarly, PE investments present a large concentration. However, such investments exhibit a higher dispersion than VC investments. This result resembles the results obtained in other studies (Bender \& Lutz, 2009).

The difficulty of obtaining data on the PE/VC industry in Brazil and other developing countries is one of the limitations of this study. In this respect, it was impossible with the database that we used to designate a statistically defensible control group. Therefore, the analysis was based on a comparison between PE and VC investments in relation to the stage of development of the investee companies. In addition, causality could not be argued because the distance between managers and investee companies is not a purely endogenous variable. However, the variable's influence on the investment decision is defensible. Thus, it is possible to assert that VC risk capital fund managers tend to invest in companies that are located closer to their head offices than PE risk capital firms and that the likelihood of a company that received a $\mathrm{VC}$ investment instead of a PE investment (going from 0 to 1 ) it is expected have a 1.64 decrease in the log odds of being in a higher level category of distance from the fund manager.

The importance of the distance between managers and investees strengthens the argument for the existence of regional institutional void caused by the concentration of PE/VC fund managers in Brazil's Southeastern Region. In addition, the research presents relevant practical implications for entrepreneurs, PE/VC fund managers and primarily public managers by demonstrating how the different variables influence the geographic distribution of the industry in the country. Through INOVAR, FINEP was successful in developing Brazil's risk capital industry. However, this model could not able spread its success to the Northern, Northeastern and Central-Western regions. If the phenomenon of $\mathrm{VC}$ investment clustering occurs in developed economies, there are mechanisms to decrease the regional equity gap, particularly in areas with high-impact startup companies (e.g., Pernambuco State). For example, in the United States, the mechanism of syndication (co-investment) in the same round of investment is common (Sorensen \& Stuart, 2001). Therefore, it is necessary to develop managers in these regions and build bridges to more highly capitalized managers from the Southeastern Region. 


\section{References}

Agência Brasileira de Desenvolvimento Industrial (ABDI) \& Fundação Getúlio Vargas (FGV). 2011. A indústria de private equity e venture capital -Segundo censo brasileiro [The private equity and venture capital industry—Second Brazilian census]. Brasília and São Paulo: ABDI and FGV.

Aidis, R. 2005. Institutional barriers to small- and medium-sized enterprises operations in transitions countries. Small Business Economics, 25(4): 305-317.

Achleitner, A. K., Marko B., Reiner B. and Annabell G. (2009), Community Development Venture Capital: Concept and Status Quo in Germany, International Journal of Entrepreneurship and Innovation Management, 9, 437-452.

Achleitner, A.K.; Bender, Marko; Kaserer, C.; Lutz, E. (2010): Geographic location of a new venture and the likelihood of a venture capital investment, CEFS working paper series, No. 2010-02.

Audretsch, D. B., Keilbach, M., \& Lehmann, E. E. 2006. Entrepreneurship and economic growth. Oxford: Oxford University Press.

Avnimelech, G., Schwartz, D., \& Bar-El, R. 2007. Entrepreneurial high-tech cluster development: Israel's experience with venture capital and technological incubators. European Planning Studies, 15(9): 1181-1198.

Barry, C. 1990. The role of venture capital in the creation of public companies. Journal of Financial Economics, 27: 447-471.

Bender, M., \& Lutz, E. 2009. Patterns in spatial proximity between venture capital investors and investees in Germany: An empirical analysis. CEFS working paper series, No. 2009-06. Kiel, Germany: Leibniz Information Centre for Economics.

Carvalho, A. G., Ribeiro, L. L., \& Furtado, C. V. 2006. A indústria de private equity e venture capital-Primeiro censo brasileiro [The private equity and venture capital industry-First Brazilian census]. São Paulo: Saraiva Publisher.

Chen, K., Liu, Y., \& Chen, Q. 2009. How much does history matter? An analysis of the geographic distribution of venture capital investment in the U.S. biotechnology industry. Industrial Geographer, 6(2): 31-55.

Chen, H., Gompers, P., Kovner A., Lerner, J. 2010. Buy local? The geography of venture capital. Journal of Urban Economics, 67: 90-102.

Cumming, D. 2007. Government policy towards entrepreneurial finance: Innovation investment funds. Journal of Business Venturing, 22(2): 193-235.

Florida, R. L., \& Kenney, M. 1988. Venture Capital High Technology and regional development. Regional Studies, 22(1): 33-48.

Fritsch, M., \& Schilder, D. 2008. Does venture capital investment really require spatial proximity? Environment and Planning, 40(9): 2114-2131.

Gompers, P., \& Lerner, J. 1999. The venture capital cycle. Cambridge, MA: MIT Press.

Green, M. 2004. Venture capital investments in the United States 1995-2002. Industrial Geographer, 2(1): 2-28.

Harding, R. 2000. Venture capital and regional development: Towards a venture capital 'system.' Venture Capital, 2(4): 287-311.

Hellmann, T., \& Puri, M. 2000. The interaction between product market and financing strategy: The role of venture capital. Review of Financial Studies, 13: 959-984.

Keilbach, M., Tamvada, J. P., \& Audretsch, D. B. 2009. Sustaining entrepreneurship and economic growth. New York: Springer-Verlag. 
Khana, T., \& Palepu, K. 1997. Why Focused strategies may be wrong for emerging markets. Harvard Business Review, 75(4): 41-51.

Kollmann, T., \& Kuckertz, A. 2010. Evaluation uncertainty of venture capitalists investment criteria. Journal of Business Research, 63(7), 741-747.

Larson, A., \& Starr, J. A. 1993. A network model of organization formation. Entrepreneurship, Theory \& Practice, 17(2), 5-15.

Leinbach, T., \& Amrhein, C. 1987. A geography of the venture capital in the U.S. Professional Geographer, 39: 146-158.

Lerner, J. Venture capitalists and the oversight of private firms. Journal of Finance, 50(1), 301318.1995

Lerner, J., \& Watson, B. 2008. The public venture capital challenge: The Australian case. Venture Capital, 10(1): 1-20.

Liu, Y. 2011. High-tech ventures' innovation and influences of institutional voids: A comparative study of two high-tech parks in China. Journal of Chinese Entrepreneurship, 3(2): 112-133.

Luthans, F., \& Ibrayeva, E. S. 2006. Entrepreneurial self-efficacy in Central Asian transition economies: Quantitative and qualitative analysis. Journal of International Business Studies, 37(1): 92-110.

Lutz, E., et al. 2013. Importance of Spatial Proximity between Venture Capital Investors and Investees in Germany. Journal of Business Research, 66(11), 2346-2354.

Manolova, T. S., Euni, R. V., \& Gyoshev, B. S. 2008. Institutional environments for entrepreneurship: Evidence from emerging economies in Eastern Europe. Entrepreneurship Theory and Practice, 32(1): 203-218.

Martin, R., Bernard, C., Klagge, B., \& Sunley, R. 2005. Spatial proximity effects and regional equity gaps in the venture capital market: Evidence from Germany and the United Kingdom. Environment and Planning, 37(7): 1207-1231.

Mendonça, M. 2008. Política de inovação no Brasil e seus impactos sobre as estratégias de desenvolvimento tecnológico empresarial [Innovation policy in Brazil and its impact on the business strategies for corporate technological development]. Revista $T \& C$ Amazônia, ano VI(13): 29.

Michael, S. C., \& Pearce, J. A. 2009. The need for innovation as a rationale for government involvement in entrepreneurship. Entrepreneurship and Regional Development, 21(3): 285302.

Minniti, M. 2008. The role of government policy on entrepreneurial activity: Productive, unproductive, or destructive? Entrepreneurship Theory and Practice, 32(5): 779-790.

Pavani, C. 2003. O capital de risco no Brasil-Conceito evolução perspectivas [Risk capital in Brazil-Concept development prospects]. São Paulo: E-papers Publisher.

Peci, F., Kutlovci, E., Tmava, Q., \& Shala, V. 2012. Small and medium enterprises facing institutional barriers in Kosovo. International Journal of Marketing Studies, 4(1): 95-107.

Sapienza, H. J., \& De Clercq, D. 2000. Venture capitalist-entrepreneur relationships in technology-based ventures. Enterprise and Innovation Management Studies, 1(1), 57-71.

Sapienza, H. J., \& Gupta, A. K. 1994. Impact of agency risks and task uncertainty on venture capitalist-CEO interaction. Academy of Management Journal, 37(6), 1618-1632.

Sapienza, H. J., \& Korsgaard, M. A. 1996. Procedural justice in entrepreneur-investor relations. Academy of Management Journal, 39(3), 544-574.

Shane, S., \& Cable, D. 2002. Network ties, reputation, and the financing of new ventures. Management Science, 48(3), 364-381.

Smallbone, D., \& Welter, F. 2001. The role of government in SME development in transition countries. International Small Business Journal, 19(4): 63-77. 
Sorenson, O., \& Stuart, T. E. 2001. Syndication networks and the spatial distribution of venture capital investments. American Journal of Sociology, 106(6): 1546-1588.

Subhash, K. B. 2007. Geography of venture capital financing in Canada. Journal of Private Equity, 11(1): 93-107.

Sunley, P., Klagge, B., Berndt, C., \& Martin, R. 2005. Venture capital programmes in the UK and Germany: In what sense regional policies? Regional Studies, 39(2): 255-273.

Williamson, O. E. 1981. The economics of organization: The transaction cost approach. The American Journal of Sociology, 87(3), 548-577.

Zhang, J. 2011. The spatial dynamics of globalizing venture capital in China. Environment and Planning, Part A, 43(7): 1562-1580.

Zook, M. A. 2002. Grounded capital: venture financing and the geography of the internet industry. Journal of Economic Geography, 2: 151-177.

Zook, M. A. 2004. The knowledge brokers: Venture capitalists, tacit knowledge and regional development. International Journal of Urban and Regional Research, 28(3): 621-641. 